\title{
Considerations regarding the anti-icing system for the ship propulsion plant with gas turbine
}

\author{
George Iulian Balan ${ }^{1}$, Octavian Narcis Volintiru ${ }^{2}$, Ionut Cristian Scurtu ${ }^{2 *}$, Florin Ioniță ${ }^{2}$, \\ Mirela Letitia Vasile $^{1}$, and Claudia Borzea $^{1}$ \\ 1. National Research and Development Institute for Gas Turbines COMOTI, București, România \\ 2. Mircea cel Batran Naval Academy, Constanta, Romania
}

\begin{abstract}
Vessels that have navigation routes in areas with ambient temperatures that can drop below $+5\left[{ }^{\circ} \mathrm{C}\right]$, with a relative humidity of over $65 \%$, will have implemented technical solutions for monitoring and combating ice accumulations in the intake routes of gas turbine power plants. Because gas turbines are not designed and built to allow the admission of foreign objects (in this case - ice), it is necessary to avoid the accumulation of ice through anti-icing systems and not to melt ice through defrost systems. Naval anti-icing systems may have as a source of energy flow compressed air, supersaturated steam, exhaust gases, electricity or a combination of those listed. The monitoring and optimization of the operation of the anti-icing system gives the gas turbine power plant an operation as close as possible to the normal regimes stipulated in the ship's construction or retrofit specification.
\end{abstract}

Anti-icing $=$ to prevent the ice accrual

De-icing $=$ removing the ice from the inlet ducts and/or the inlet flare of gas turbine (highly not recommended during running).

\section{Structural details about ST40M gas turbine propulsion system}

The system is built around of the (Pratt\& Whitney) ST40M gas turbine and it is a retrofitting project named TURBONAV and a main contractor for the research and development was nominated The National Research and Development Institute for Gas Turbines COMOTI.As per the Fig.1., following the gas path there can be identified the ship air intake, air intake duct, ST40M gas turbine, exhaust duct and the ship uptake. Propulsion power is transferred from the power turbine to the torque tube via a high speed clutch and from the torque tube to the primary gearbox.

\footnotetext{
*Corresponding author: scurtucristian@yahoo.com
} 


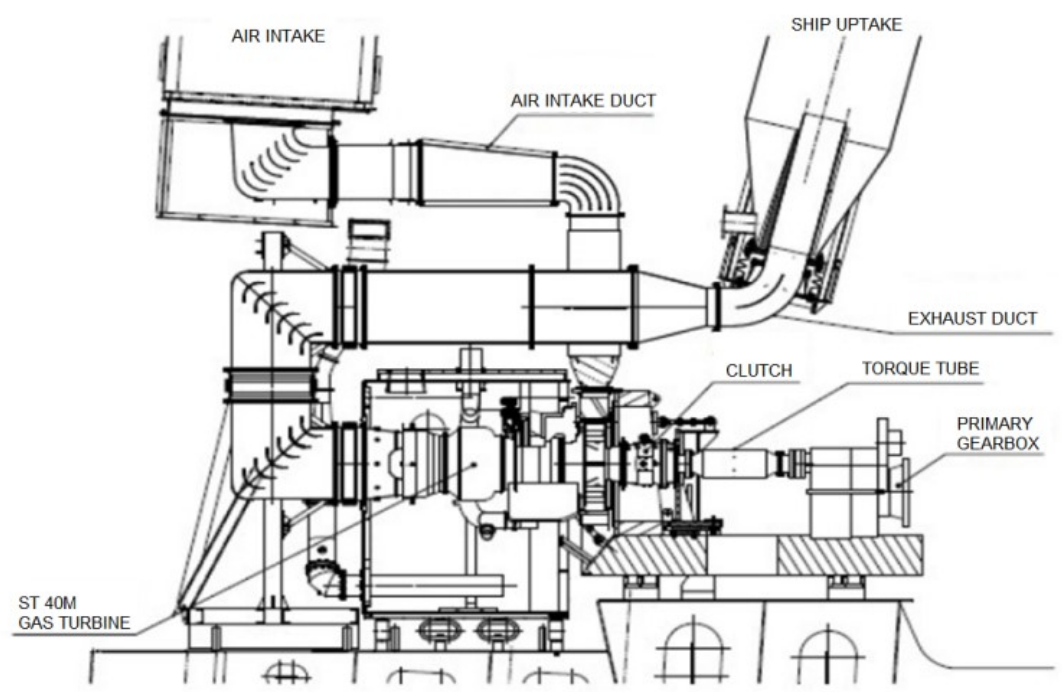

Fig. 1.Energetic system with ST40M gas turbine[19]

\section{Air intake parameters}

\begin{tabular}{|l|l|l|l|l|}
\cline { 2 - 5 } \multicolumn{1}{c|}{} & \multicolumn{2}{c|}{ Wet (1:1 water: fuel) } & \multicolumn{2}{c|}{ Dry } \\
\cline { 2 - 5 } \multicolumn{1}{c|}{} & Power & Heat rate & Power & Heat rate \\
\hline Peak Rating & $7183 \mathrm{shp}$ & $7921 \mathrm{Btu} / \mathrm{hph}$ & $6576 \mathrm{shp}$ & $7595 \mathrm{Btu} / \mathrm{hph}$ \\
& $5357 \mathrm{~kW}$ & $10611 \mathrm{Btu} / \mathrm{kWh}$ & $4904 \mathrm{~kW}$ & $10185 \mathrm{Btu} / \mathrm{kWh}$ \\
\hline Base Rating & $6089 \mathrm{shp}$ & $7916 \mathrm{Btu} / \mathrm{hph}$ & $5416 \mathrm{shp}$ & $7688 \mathrm{Btu} / \mathrm{hph}$ \\
& $4547 \mathrm{~kW}$ & $10615 \mathrm{Btu} / \mathrm{kWh}$ & $4039 \mathrm{~kW}$ & $10310 \mathrm{Btu} / \mathrm{kWh}$ \\
\hline
\end{tabular}

Fig. 2.ST40M Gas turbine functional parameters [20]

- mass air flow: $\dot{\mathrm{m}}_{\mathrm{a}}[\mathrm{kg} / \mathrm{s}]$

- forecast ambient temperature for icingt $t_{\mathrm{amb}}=\left(-20^{\circ} \mathrm{C} \div+5^{\circ} \mathrm{C}\right)$

- icing conditions:

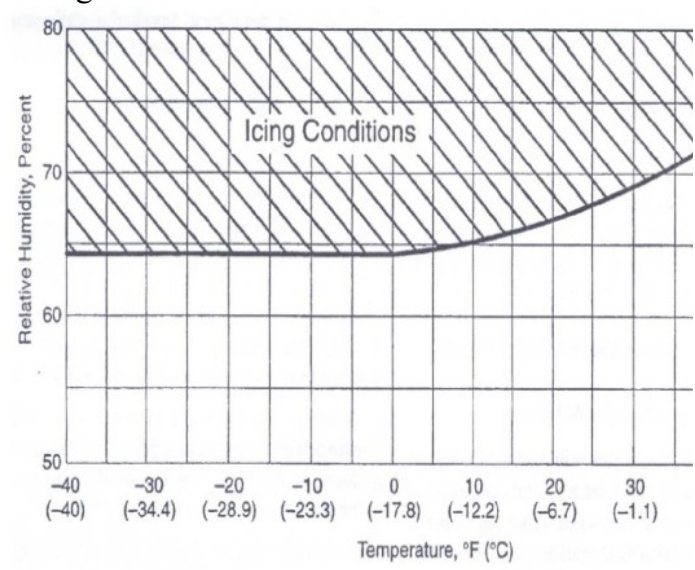

Fig. 3.Icing condition Rolls Royce [8]

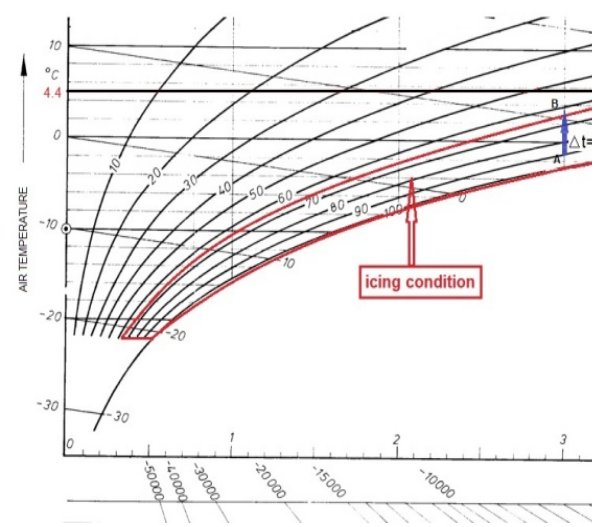

Fig. 4.Icing condition in according to the 


$$
\begin{gathered}
\mathrm{t}\left[{ }^{0} \mathrm{~F}\right]=32+1.8 \mathrm{t}\left[{ }^{0} \mathrm{C}\right] \\
\mathrm{t}\left[{ }^{0} \mathrm{C}\right]=\left(\mathrm{t}\left[{ }^{0} \mathrm{~F}\right]-32\right) / 1.8
\end{gathered}
$$

\begin{tabular}{|c|c|c|c|c|c|c|c|c|c|}
\hline $\mathbf{t}^{\mathbf{0}} \mathbf{C}$ & -40 & -30 & -10 & 0 & 5 & 10 & 15 & 30 & 40 \\
\hline $\mathbf{t}^{\mathbf{0}} \mathbf{F}$ & -40 & -22 & 14 & 32 & 41 & 50 & 59 & 86 & 104 \\
\hline
\end{tabular}
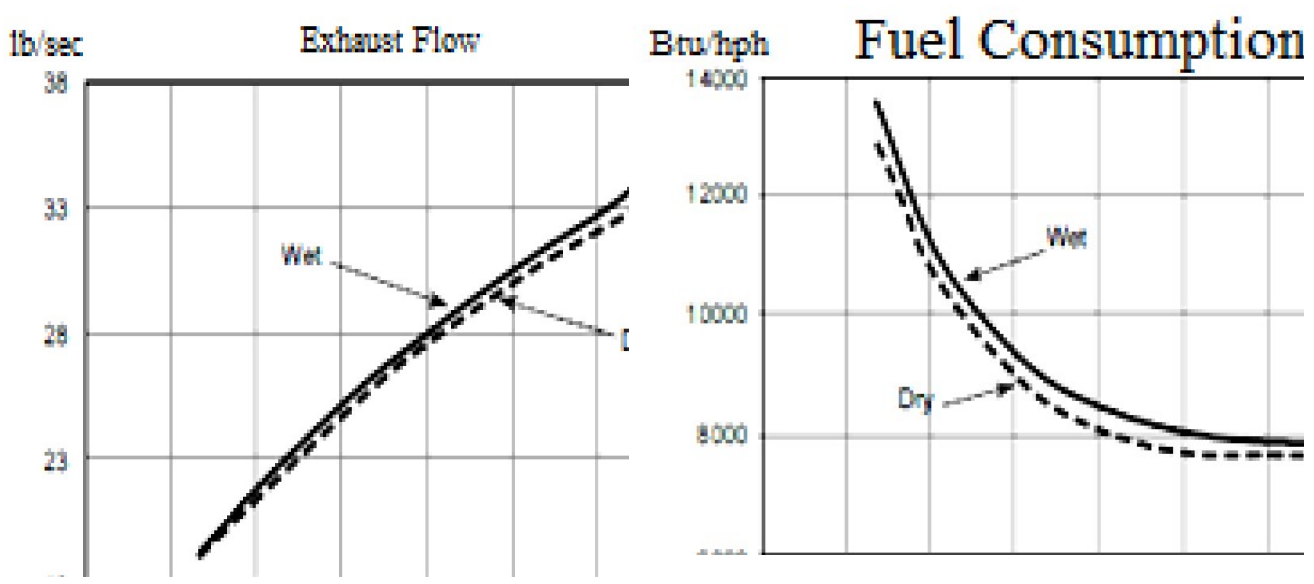

Fig. 5.ST40M Exhaust Flow chart [20] Fig. 6.ST40M Fuel Consumption chart [20]

\section{Energetically fluxes for the gas turbine air intake}
A. Electric energetically flux
B. Hot air energetically flux

B1. Energy flow exchanger (hot air and intake air)

B2. Hot air injection in the air intake duct

C. Exhaust gas energetically flux

C1. Energy flow exchanger (exhaust gas and intake air)

C2. Exhaust gas injection in the air intake duct

D. Steam energetically flux

D1. Energy flow exchanger (steam and intake air)

D2. Steam injection in the air intake duct.

E. Ballast water energetically flux

E1. Energy flow exchanger (ballast water and intake air)

By using the data from the fuel consumption diagram (Fig. 6.), the sea trial parameters [13] and the following equations we can find the functional parameters for the ST40M gas turbine propulsion system. The calculus is based on F75/F76 NATO fuel, on wet and dry running.

$$
\begin{gathered}
1[\mathrm{HP}]=0.736[\mathrm{KW}] \\
10000[\mathrm{BTU} / \mathrm{h}]=2.93[\mathrm{KW}] ; 10000[\mathrm{BTU}]=2.93[\mathrm{KWh}] \\
10000\left[\frac{\mathrm{BTU}}{\mathrm{HPh}}\right]=\frac{2.93}{0.736}\left[\frac{\mathrm{KWh}}{\mathrm{KWh}}\right]=3.98\left[\frac{\mathrm{KWh}}{\mathrm{KWh}}\right]
\end{gathered}
$$




$$
\begin{aligned}
& \mathrm{Qi}=42700\left[\frac{\mathrm{KJ}}{\mathrm{Kg}}\right] \text { - Lower Heating Value; } \mathrm{C}_{\mathrm{h}}[\mathrm{Kg} / \mathrm{h}] \text { - fuel consumption } \\
& \mathrm{P}_{\mathrm{e}_{\mathrm{TGP}}} \cong 0.33 \cdot \mathrm{P}_{\mathrm{ITG}}[\mathrm{KW}] \text { - Propulsion effective power } \\
& \dot{\mathrm{Q}}_{\mathrm{d}}=\frac{\mathrm{C}_{\mathrm{h}} \cdot \mathrm{Qi}}{3600} \text { - available energy flow } \\
& \dot{\mathrm{Q}}_{\mathrm{d}}=\mathrm{RE} \cdot \mathrm{P}_{\mathrm{ITG}} ; \mathrm{RE}-\text { energy ratio } \\
& \mathrm{C}_{\mathrm{h}}=\frac{\mathrm{RE} \cdot \mathrm{P}_{\text {ITG }} \cdot 3600}{\mathrm{Q}_{\mathrm{I}}}-\text { fuel consumption } \\
& \rho_{\mathrm{M}}=0.84\left[\frac{\mathrm{Kg}}{\mathrm{l}}\right] \text { - fuel density } \\
& \mathrm{P}_{\text {prop }}=\mathrm{C}_{\mathrm{N}} \cdot \mathrm{V}_{\mathrm{N}}^{3}[\mathrm{KW}]-\text { ship propulsion power } \\
& \mathrm{C}_{\mathrm{N}}=5.87-\text { ship resistance coefficient* } \\
& \text { * it was determinate after sea trial in } 2019 \\
& 1 \mathrm{Kn}=\frac{1852}{3600}\left[\frac{\mathrm{m}}{\mathrm{s}}\right]=0.514\left[\frac{\mathrm{m}}{\mathrm{s}}\right] \\
& \mathrm{V}_{\mathrm{N}}=\left(\frac{\mathrm{P}_{\text {prop }}}{\mathrm{C}_{\mathrm{N}}}\right)^{1 / 3}\left[\frac{\mathrm{m}}{\mathrm{s}}\right] \text { - ship speed }
\end{aligned}
$$

\section{Anti-icing parameters}

The exhaust gas mass flow rate:

$\dot{\mathrm{m}}_{\text {gaze }}=15.7[\mathrm{~kg} / \mathrm{s}]$ at ambient temperature $0^{\circ} \mathrm{C}$

Specific fuel consumption:

$$
\mathrm{c}_{\mathrm{e}}=1089[\mathrm{~kg} / \mathrm{h}]=0.3025[\mathrm{~kg} / \mathrm{s}]
$$

The air intake mass flow rate:

$$
\begin{aligned}
& \dot{\mathrm{m}}_{\text {aer }}=\dot{\mathrm{m}}_{\text {gaze }}-\mathrm{c}_{\mathrm{e}}=15.7-0.3025=15.3975[\mathrm{~kg} / \mathrm{s}] \\
& \dot{\mathrm{m}}_{\mathrm{aer}}=0.3025 \cdot \alpha \cdot 13.8
\end{aligned}
$$

From where the air excess coefficient is: $\alpha=3.688$.

The necessary energetically flux for anti-icing (when the total amount of the air intake is heated):

For $\quad \Delta \mathrm{t}=5^{\circ} \mathrm{C} . \mathrm{c}_{\mathrm{p}}=1.01[\mathrm{~kJ} / \mathrm{kg} \operatorname{grad}]$

$\dot{\mathrm{Q}}_{\mathrm{nec} 5}=\dot{\mathrm{m}}_{\mathrm{aer}} \cdot \mathrm{c}_{\mathrm{p}} \cdot \Delta \mathrm{t}$

$\dot{\mathrm{Q}}_{\text {nec5 }}=15.3975 \cdot 1.01 \cdot 5=\mathbf{7 7 . 7 6}[\mathbf{k W}]$

For $\quad \Delta \mathrm{t}=6^{\circ} \mathrm{C}, \mathrm{c}_{\mathrm{p}}=1.01[\mathrm{~kJ} / \mathrm{kg} \operatorname{grad}]$

$\dot{\mathrm{Q}}_{\text {nec } 6}=\dot{\mathrm{m}}_{\mathrm{aer}} \cdot \mathrm{c}_{\mathrm{p}} \cdot \Delta \mathrm{t}$

$\dot{\mathrm{Q}}_{\text {nec } 6}=15.3975 \cdot 1.01 \cdot 6=\mathbf{9 3 . 3}[\mathbf{k W}]$

For $\quad \Delta \mathrm{t}=10^{\circ} \mathrm{C}, \mathrm{c}_{\mathrm{p}}=1.01[\mathrm{~kJ} / \mathrm{kg} \operatorname{grad}]$

$\dot{\mathrm{Q}}_{\mathrm{nec} 10}=\dot{\mathrm{m}}_{\mathrm{aer}} \cdot \mathrm{c}_{\mathrm{p}} \cdot \Delta \mathrm{t}$

$\dot{\mathrm{Q}}_{\text {nec } 10}=15.3975 \cdot 1.01 \cdot 10=\mathbf{1 5 5 . 5 1}[\mathbf{k W}]$

For $\quad \Delta \mathrm{t}=20^{\circ} \mathrm{C}, \mathrm{c}_{\mathrm{p}}=1.01[\mathrm{~kJ} / \mathrm{kg}$ grad $]$

$$
\begin{aligned}
& \dot{\mathrm{Q}}_{\text {nec } 20}=\dot{\mathrm{m}}_{\mathrm{aer}} \cdot \mathrm{c}_{\mathrm{p}} \cdot \Delta \mathrm{t} \\
& \dot{\mathrm{Q}}_{\text {nec } 20}=15.3975 \cdot 1.01 \cdot 20=\mathbf{3 1 1 . 0 2}[\mathbf{k W}]
\end{aligned}
$$

\section{Electric anti-icing system proposal, version 1:}


Fitting of electric heating coils inside of the transition duct between splitter box and cascade bend of the ST40M gas turbine air intake.

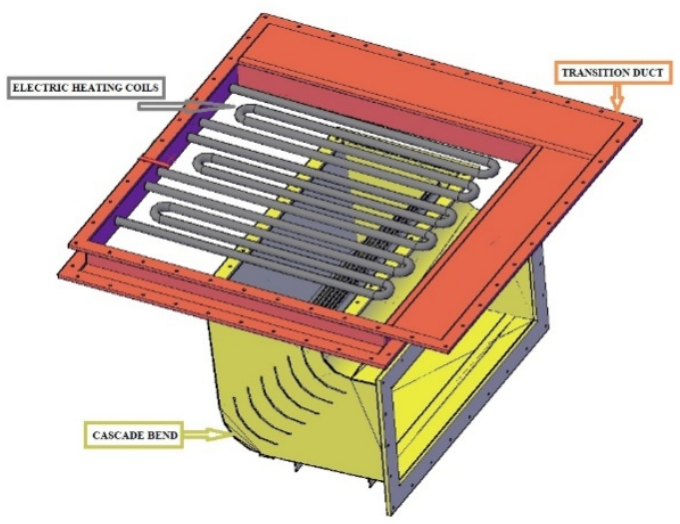

Fig. 7.Anti-icing system version 1

According with the material description sheets from the heating systems producer Chromalox, a single electric heating coil in 3 [m] length, heaving a 29 [mm] diameter it is able to generate an energetic flux of 10 [KW].

For heating-up the total amount of the gas turbine air intake with $6\left[{ }^{\circ} \mathrm{C}\right]$ there will be necessary to install 9 electric Fintube heating coils. The powering of the anti-icing systems will require 120 [KW], 440 [V] from the ship power grid.

In Fig. 7.there are shown only three electric Fintube heating coils and, therefore, a total energetically flux of $30[\mathrm{KW}]$ and, for the above example will be necessary to install another two layers of coils (9 heating coils in total) for generating 90 [KW].

\section{Electric anti-icing system proposal, version 2}

Fitting of electric heating coils outside of the cascade bend.

Using this version of the electric anti-icing system will ensure that the air flow is not perturbed and will be no any additional pressure losses inside of the air intake duct.

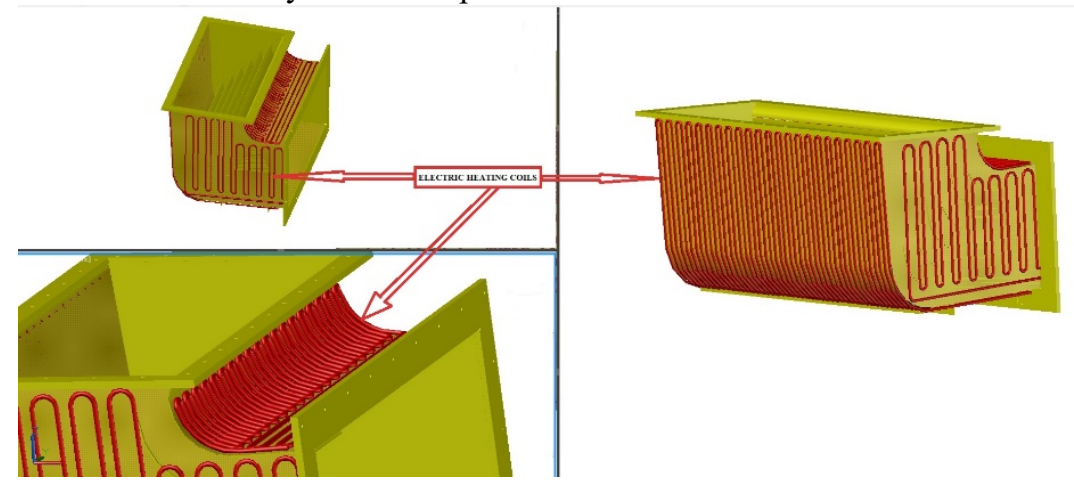

Fig. 8. Anti-icingsystemversion 2

Using this electric heating coils arrangement there will be a $2.5\left[\mathrm{~m}^{2}\right]$ heated area and will act as a heat exchanger. There will be necessary to thermal insulate the cascade bend to minimise the energy flux escaping outside. 


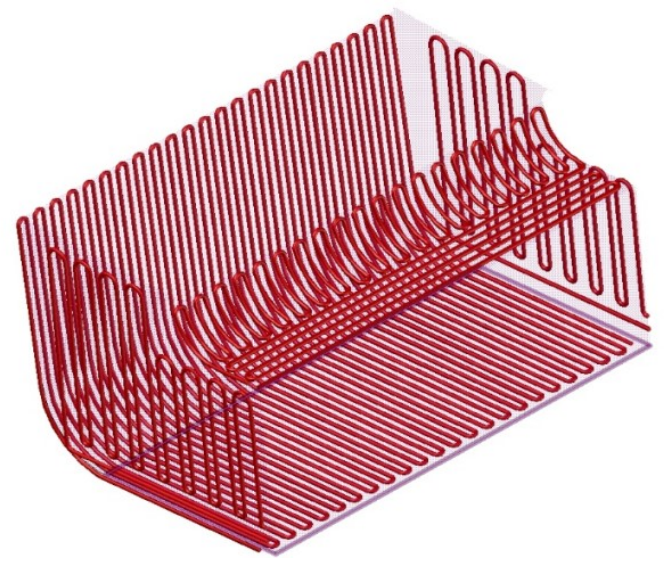

Fig.9.Anti-icing system version 2 - details

\section{Thermal anti-icing system - proposal}

The most ships propelled by the energetically installations with gas turbine are using the anti-icing systems based on energy fluxes from compressed air, steam or exhaust gas.

Transmission of the energy fluxes from a thermal agent to the intake air can be done by heat exchangers or by direct injection of the thermal agent in the air intake duct.

For the retrofitting project where there is no steam generator already installed, this system will have to be based on compressed air or on exhaust gas.

The exhaust gas can be leaded through a heat exchanger installed inside of the air intake duct. This system will generate structural modifications and will introduce power losses in the air flow.

Exhaust gas direct injection will be a proper solution for the anti-icing due to high temperature thermal agent but it will be necessary to be accepted by the gas turbine manufacturer.

In Fig. 10.is shown an anti-icing system using the energy flow from the direct injected compressed air produced by the gas turbine compressor [3]. This technical solution for the anti-icing system is the most used for the navy ships, is robust, easy in control and easy to be implemented in case of ship retrofitting. By using a certain amount of the gas turbine compressed air it will reduce the delivery power of the entire propulsion system.
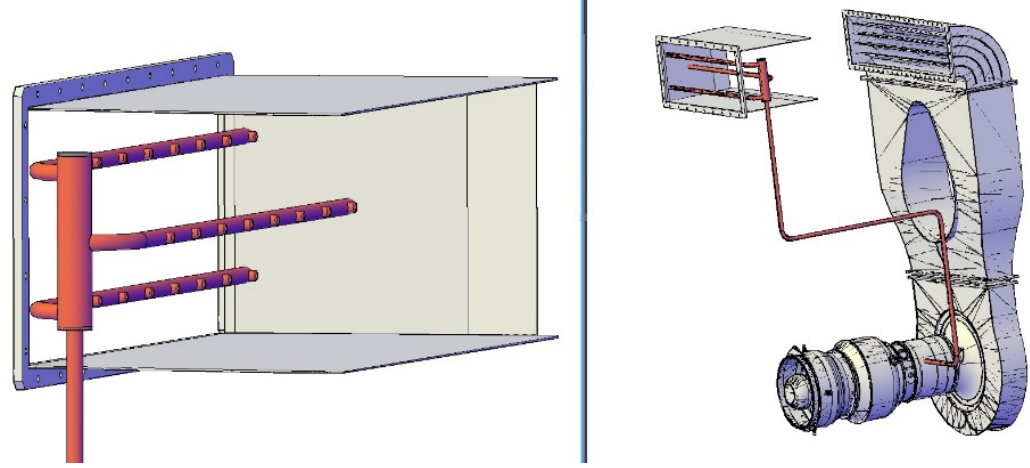

Fig. 10. Anti-icing system with compressed air 
Conforming to the ST40M installation manual there is the possibility to extract an amount of maximal $10 \%$ of the compressed air mass flow ( $6 \%$ from the LP compressor and $10 \%$ from the HP compressor but not more than $10 \%$ from the compressed air mass flow in total).

Therefore, that is possible to extract the compressed air from LP system having maxim temperature $\mathbf{t}_{\mathbf{L P}}=+282\left[{ }^{\circ} \mathrm{C}\right]$ with a mass flow of $6[\%]$ from total intake air mass flow $(6$ $[\%] \cdot 15.3975[\mathbf{k g} / \mathbf{s}]=\mathbf{0 . 9 2}[\mathbf{k g} / \mathbf{s}]$ )or compressed air from HP system having maxim temperature $\mathbf{t}_{\mathbf{H P}}=+510\left[{ }^{\circ} \mathrm{C}\right]$ la with a mass flow of $10[\%]$ from total intake air mass flow $(10[\%] \cdot 15.3975[\mathrm{~kg} / \mathrm{s}]=1.54[\mathrm{~kg} / \mathrm{s}])$.

Calculus of the compressed air mass flow used for the anti-icing system will be done by expressions of the enthalpy balance against of the reference temperature. We will consider the reference temperaturet $\mathrm{amb}_{\mathrm{a}}=+15\left[{ }^{\circ} \mathrm{C}\right]$ and a specific heat of the intake air at constant pressurec $_{\mathrm{p}}=1.01[\mathrm{~kJ} / \mathrm{kg}$ grad $]$.

The enthalpy balance equations:

$\dot{\mathrm{Q}}_{\text {intake }}=\dot{\mathrm{m}}_{\text {intake }} \cdot \mathrm{c}_{\mathrm{p}} \cdot \Delta \mathrm{T}_{\text {intake }}$

$\dot{\mathrm{Q}}_{\text {intake }}=\dot{\mathrm{m}}_{\mathrm{amb}} \cdot \mathrm{c}_{\mathrm{p}} \cdot\left(\mathrm{T}_{\mathrm{amb}}-288.15\right)+\dot{\mathrm{m}}_{\mathrm{comp}} \cdot \mathrm{c}_{\mathrm{p}} \cdot\left(\mathrm{T}_{\mathrm{comp}}-288.15\right)$

From where we can findm $\dot{\mathrm{m}}_{\text {comp }}$ depending of the temperature difference $\Delta \mathrm{T}_{\text {intake }}$ for the anti-icing system:

$\dot{\mathrm{m}}_{\text {comp }}=\left[\dot{\mathrm{m}}_{\text {intake }} \cdot \Delta \mathrm{T}_{\text {intake }}-\dot{\mathrm{m}}_{\text {amb }} \cdot\left(\mathrm{T}_{\mathrm{amb}}-288.15\right)\right] /\left(\mathrm{T}_{\text {comp }}-288.15\right)$

For the case when it is extracted the compressed air from the LP system we will admit $\Delta \mathrm{T}_{\text {intake }}=6\left[{ }^{\circ} \mathrm{K}\right]=\Delta \mathrm{t}\left[{ }^{\circ} \mathrm{C}\right]$ (rising the temperature from $-3\left[{ }^{\circ} \mathrm{C}\right]$ to $+3\left[{ }^{\circ} \mathrm{C}\right]$ ) the followings are finding:

$$
\begin{gathered}
\dot{\mathrm{m}}_{\text {compLP }}=[15.3975 \cdot 6-14.4775 \cdot(270.15-288.15)] /(555.15-288.15) \\
\dot{\mathbf{m}}_{\text {compLP }}=\mathbf{1 . 3 2}[\mathbf{k g} / \mathbf{s}]
\end{gathered}
$$

For the case when it is extracted the compressed air from the HP system we will admit $\Delta \mathrm{T}_{\text {intake }}=6\left[{ }^{\circ} \mathrm{K}\right]=\Delta \mathrm{t}\left[{ }^{\circ} \mathrm{C}\right]$ (rising the temperature from $-3\left[{ }^{\circ} \mathrm{C}\right]$ to $+3\left[{ }^{\circ} \mathrm{C}\right]$ ) the followings are finding:

$$
\begin{aligned}
& \dot{\mathrm{m}}_{\text {compHP }}=[15.3975 \cdot 6-13.8577 \cdot(270.15-288.15)] /(783.15-288.15) \\
& \dot{\mathbf{m}}_{\text {compHP }}=\mathbf{0 . 6 9}[\mathbf{k g} / \mathbf{s}]
\end{aligned}
$$

From the determination of air mass flow- relations(14) and (15) there can be observed that for rising of the intake air in amount of $6\left[{ }^{\circ} \mathrm{C}\right]$ (for example: from $-3\left[{ }^{\circ} \mathrm{C}\right]$ to $+3\left[{ }^{\circ} \mathrm{C}\right]$ ) is needed a compressed airwith a mass flow equal with $\mathbf{1 . 3 2}[\mathbf{k g} / \mathbf{s}]$ from the LP system (but this amount of mass flow is not allowed to be extracted from the gas turbine LP compressor because it represented about 8.57 [\%] from the total intake air mass flow) but, at the other hand the anti-icing can be achieved by using compressed air from the HP systemwith mass flow equal with $\mathbf{0 . 7 5}[\mathbf{k g} / \mathbf{s}]$ which is about $\mathbf{4 . 4 8}[\%]$ from the total intake air mass flow.

\section{Ice accrual sensors for the anti-icing systems}

In conformity with the ship classification rules, it is mandatory to use the special designed sensors for monitoring the ice accrual inside of air tank ducts for gas turbine propulsion systems[1] [16]. 


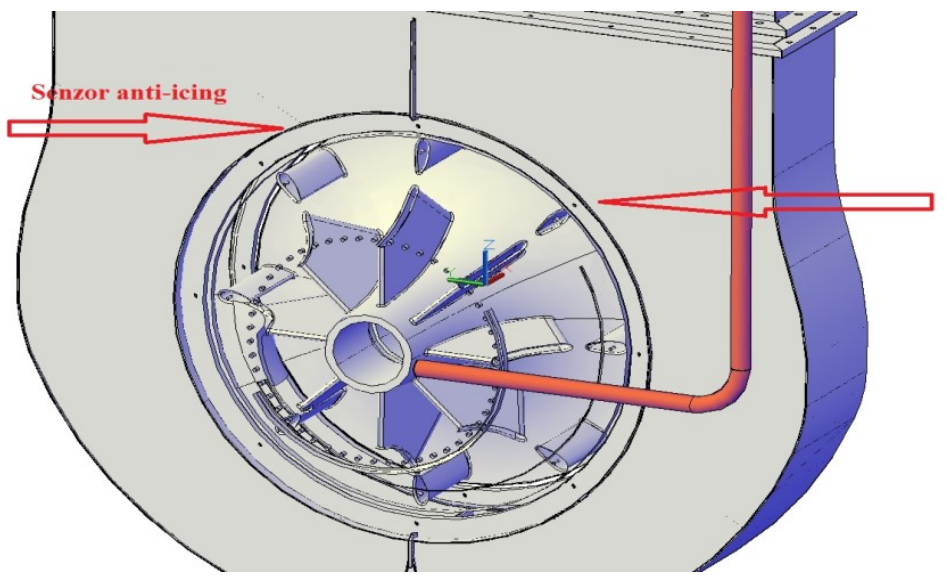

Fig. 11. Anti-icing sensor arrangement

Due to the fact that the air tank struts are the susceptible areas for the ice accrual [8] but also the inlet guide vanes and inter stage stator vanes, it is recommended to install one ice accrual sensor (if the sensors has a failing signal) or two sensors in the other cases.

\section{Conclusions}

If the electrical balance of the ship is designed to withstand an amount 180 [kW] (90 [kW] for each gas turbine) than, the electric anti-icing systems version 1 and version 2 are the best technical solutions. The main advantages of this two versions are the easiness of the installations, controlling, optimisation and monitoring of the ice accrual without using the energy flow from the propulsion system.

The anti-icing system with air compressed extracted from the gas turbine compressor is very robust and safety to use, but will not allow the propulsion system to run on maximal functional parameters. The effective propulsion power of the gas turbine energetically system will be diminished by few percents (up to $10 \%$ in power loss). The timing of the compressed airextraction, the air mass flow and duration of extraction is controlled by using ambient temperature sensors and ice accrual sensors. Due to anti-icing system optimisation the fluctuations of the effective power for propulsion can be maintained at lower level and therefore, the fuel consumption can be properly adjusted.

\section{References}

1. Military standard MIL-STD-3045, 2014, USA

2. Davis L.D., Soreng A., Twin Drive Gas Turbines in Single Propulsion Package for Norwegian Fast Patrol Boat, ASME Turbo Expo 2009, ISBN:978-0-7918-4885-2

3. Aye N., McAndtrews G., Mendenhall B., MARINE GAS TURBINE PACKAGE FOR THE KOREAN NAVY PKX PROGRAM, ASME Turbo Expo 2008, Germany, ISBN: 978-0-7918-4317-8

4. Lacey J.J., Turbine Engine Icing and Ice Detection, ASME, 1972, USA

5. Dickson J., Problems Associated with Cold Weather Operation of Gas Turbines, ASME, 1976, USA

6. Swan K.T., A survey of icing condition for marine gas turbines, NAPTC -PE-114, NAVSEC, 1977, USA 
7. Sammak M., Anti-Icing in Gas Turbines, 2006, Suedia, ISSN 0282 - 1990

8. Loud R.L., Slaterpryce A.A., Gas Turbine Inlet Air Treatment. GE technical paper GER-3419A, 1991, USA

9. Rashid T., Khawaja H.A., Edvardsen K., Review of marine icing and anti-/de-icing systems, Journal of Marine Engineering \& Technology, 15:2, 79-87,

DOI: $10.1080 / 20464177.2016 .1216734$

10. Wilcox M., s.a., GUIDELINE FOR GAS TURBINE INLET AIR FILTRATION SYSTEMS, Gas Machinery Research Council Southwest Research Institute, 2010, USA de Souza J.R.B., s.a., Thermal analysis of anti-icing systems in aeronautical velocity sensors and structures, Brazilia, J Braz. Soc. Mech. Sci. Eng. (2016) 38:14891509, DOI 10.1007/s40430-015-0449-7

11. F. Niculescu, C. Borzea, M. L. Vasile, Marine gas turbine for efficient ship propulsion, 2020, ISSN 2668-7003, ISSN-L 2457-5011,

DOI: 10.37410/EMERG.2020.3.08

12. Niculescu, F., Claudia Borzea, Adrian Savescu, Andrei Mitru, \& Mirela Letitia Vasile. (2020). Automation and Electronic Control of Marine Gas Turbine Engine for Ship Revamp. Technium: Romanian Journal of Applied Sciences and Technology, 2(4), 98108. https://doi.org/10.47577/technium.v2i4.923

13. Purece, C., Vasile Pleşca, \& Lilica Corlan. (2020). Technologies for obtaining energy from micro-hydropower resources. Technium: Romanian Journal of Applied Sciences and Technology, 2(4), 124-133. https://doi.org/10.47577/technium.v2i4.837

14. Lupchian, M. (2020). Influence of propulsion installation performance on travel efficiency. Technium: Romanian Journal of Applied Sciences and Technology, 2(7), 50-53. https://doi.org/10.47577/technium.v2i7.1644

15. Crudu, L., Bosoancă, R., \& Obreja, D. (2020). A comparative review of the resistance of a 37,000 dwt Chemical Tanker based on experimental tests and calculations. Technium: Romanian Journal of Applied Sciences and Technology, 1, 5966. https://doi.org/10.47577/technium.v1i.32

16. F.Niculescu,s.a., Automation control for revamping the propulsion system of a navy frigate, U.P.B. Sci. Bull., Series D, Vol. 83, Iss. 1, 2021, ISSN 1454-2358

17. V. Pimsner, C. A. Vasilescu, A. Petcovici, Termodinamica tehnică, 1982, Editura didactica si pedagogică, București

18. *** www.Ir.org

19. *** www.chromalox.com

20. $* * *$ www.heat-trace.com

21. $* * *$ www.comoti.ro

22. *** "ST40M-Marine and Industrial Gas turbine"-Fact sheet, Pratt \& Whitney, Canada. 